\section{Gift horse arouses suspicion}

\section{Tokyo}

WHEN a couple of Japanese academics backed by Japanese industry and the Ministry of International Trade and Industry (MITI) launched the Intelligent Manufacturing System (IMS) project earlier this year, they thought it would help ease trade friction and offer a way for Japan to pay back its technological 'debt' to the Western world.

But government officials in Washington and Brussels have taken an altogether different view. They see the project as yet another attempt by Japan to take over the world and have forced major changes.

IMS is the brainchild of a committee of academics, industrialists and MITI officials headed by Hiroyuki Yoshikawa, dean of the faculty of engineering at Tokyo University. The committee proposed an international research centre in the United States or Europe with funding over ten years of about $\$ 1,000$ million. Japanese private industry and government was to provide about 60 per cent of the total and other countries the rest.

The institute, with researchers drawn from academic institutions and industry around the world, was to have as its aim the development of new automated, standardized manufacturing systems covering all stages of manufacturing from design to retail and distribution. As Japan is a world leader in manufacturing technology, the committee (and Japanese industry) felt that Japan had much to offer. Several large US companies and the US-based Society of Manufacturing Engineers registered their approval.

But officials of the US Department of Commerce (DOC) and the European Communities (EC), see IMS as an attempt to tap Western expertise in systems integration and software. Commerce department officials are also piqued because Japan ignored government and went straight to US industry and the Society of Manufacturing Engineers for support. And the EC Commission has actively prevented European companies from joining the project, a MITI official claims.

Two major US companies, Rockwell International Overseas Corporation and United Technologies Pratt and Whitney, and the Japanese subsidiary of IBM, IBM Japan, have signed up for the project along with 62 Japanese companies covering almost all sectors of manufacturing, including FANUC (one of the world's leading manufacturers of machine tools and robots), Toyota, Nissan, NEC, Hitachi, Toshiba, Fujitsu, Sharp, NKK (a major steel producer), several companies from the giant Mitsubishi group and Kawasaki Heavy Industries.

These 'core' companies have donated $¥ 12$ million $(\$ 80,000$ ) each to finance the conceptual design of IMS. An IMS office was established in Tokyo earlier this year at a cost of over $¥ 100$ million. And in April the office began advertising for research proposals from private companies and public research institutes around the world (Nature, Classified, 19 April).

But a few days before the advertisements appeared, the EC Commission announced a counterproposal called the Future Generation Manufacturing Systems (FGMS) project. Also in April, DOC hosted a contentious meeting with 50 US companies to discuss the project and an asssistant secretary of commerce criticized the programme at a congressional hearing, describing it as an attempt by Japan to target US industries.

A meeting between US, Japanese and EC officials was held last month in Brussels. Japanese officials agreed to adopt many of the conditions of the EC's FGMS proposal and also gave DOC an equal say in the project. The result was the cancellation of the meeting, planned to take place in Tokyo last week, at which an international SUPERCONDUCTING SUPER COLLIDER

\section{Washington}

FOREIGN participation in the $\$ 8,000$ million Superconducting Super Collider (SSC), if it were to come in the form of a large cheque, would be immediately welcomed by the US Congress. But the idea that foreign governments or industries might instead prefer to do some of the high-technology manufacturing that was supposed to be a benefit of the SSC to US industry has caused political unease. Nevertheless, the team from the US Department of Energy (DOE) that visited Japan earlier this month presented Japanese government officials with a list of possible areas of participation, including construction of the superconducting mainring magnets (see Nature 345, 467; June 1990). A Japanese version of the list, which the DOE team told the press was secret, has been obtained from government officials and passed to Nature.

Devices Japan can provide for SSC: (1) Half of SSC's superconducting magnets (including collider ring magnets and dipole and quadrupole magnets for $\mathrm{HEB}^{*}$ ).

(2) Components for large SSC particle detectors

(3) Other possible fields (a) Collider and HEB [High Energy Booster, the penultimate accelerating ring, which feeds protons into the main ring.] ultra-low temperature equipment (half); (b) Power supply components for magnets; (c) Ultra-low temperature connectors (spool parts); (d) Iron and steel parts; (e) Magnets committee of academics was to examine research proposals (see Nature 343, 496; 1990) and map out details of the project. Instead, the United States and EC are to deal separately with projects from their own participants.

Before the change was announced, the IMS office had received nearly a hundred proposals, 68 from Japan, 14 from North America, 12 from Europe and 1 from Australia. Most of the proposals (56) come from private industry, the rest (39) from public research institutes.

The United States, EC and Japan will each put forward projects at a September meeting in Tokyo. According to the Brussels agreement, each collaboration "must provide a balanced flow of knowledge". The revisions have converted what was intended by Japan to be largely a privatesector initiative into a highly political government-controlled project. MITI officials do not seem to be concerned about this change, but Japan's private industry, which required considerable persuasion to begin the project in the first place, is beginning to have second thoughts about contributing to the project.

David Swinbanks

\title{
US wish-list secrets
}

for large detectors; (f) Support construction of underground tunnel. And provide boring machines; $(\mathrm{g})$ Money.

The items on the list (note that one of them is not strictly speaking a 'device') were assembled by DOE officials with the assistance of SSC director Roy Schwitters.

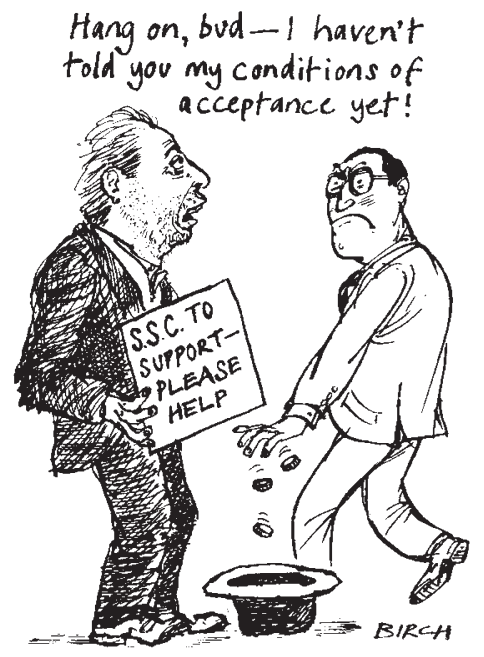

An SSC spokesman said that US manufacturers with whom SSC physicists and engineers have been in contact had taken a "statesmanlike attitude" to the idea that other countries might help build some parts of the $20 \mathrm{TeV}$ accelerator, and that worries over technology transfer were largely a Washington problem.

David Swinbanks \& David Lindley 